\title{
The Western Acknowledgment of the Invasion of Albania by the Italians (1939) (Backed Up by the British Archives)
}

\author{
Sereta Koperaj, MA \\ Assoc.Prof.Dr. Nertila Haxhia Ljarja \\ University of Shkodra "Luigj Gurakuqi”, Shkoder, Albania
}

\section{Doi:10.5901/ajis.2014.v3n6p275}

\begin{abstract}
The Albanian Kingdom in the years 1930, being the newest state since the Ottoman empire invasion, began to strengthen its institutional structures and it began to establish political transparency under King Zog. After two wars in the Ballkans, this country became independent inspite of all the difficulties and the lack of help from the sorrounding countries. The new countries in the Ballkan came from a background of dependency from the Ottoman Empire therefore they chose to remain integrated towards the Higher Power instead of claiming their independency.1 This means that the Higher Power which are the countries with the strong political influence began to control and lead these South Eastern European countries. France, Italy and Great Britain played the main part in this. France, which strongly backed the Serbo-Croat empire (future Yougoslavia) had the most influential politics after the first world war. On the other hand, Italy was more interested in Albania and the reason being that they could fulfill their future plans of expansion towards the east together with the ownership of the Adriatic Sea.
\end{abstract}

Nevertheless, Britain was strongly interested in keeping a steady equilibrum politically by minimising rivalry by France and controlling any motives into expansion by Italy. This meant however that the relationship between Great Britain and Italy was damaged between the years of 1920-1930. Starting from the Treaty of London (26.04.1915) and into the Peace Conference in Paris (1919-1920), Great Britain accepted a project by Italy into the dominion of Albania although not fully. The reason for their reluctance was that it would create problems in the region and further disrupt any relationships. What is really important to mention is that although for Albanians in their expansion the problem was an ethical one, for the Higher powers this was only a small problem in the grand scheme of things. In the Ambassador conference, (1921) the Italian representative asked that Italy be recognised as a political and economical power in Albania but they were opposed by Britain in this case ${ }^{2}$. Even though at the time, Albania was of no interest to Britain, after the year 1920 it began to be considered as important. It is for this reason alone that Albania was handled with care in the case against Italy. The reason that the Higher Political powers restricted Italy in its invasion was because there would be a matter of conflict between Italy and Slavic countries and it could even have gone as far as to disrupt the relationship with France as they at the time, fully backed Yougoslavia. The destabilisation of Albania could even have disrupted Greece and any interest that Britain may have had there. Although Great Britain did not have a special interest in Albania, they considered our independence to be very important. It is for this reason that the matter required delicate handling especially concerning Italy and its plans for Albania. The reasons why the special forces became very aware of our situation is because of the aggravation that could be caused between Italy and France and also the destabilization of Albania could in fact hurt Greece and in the long run even Britain and its interests. Great Britain also had economical investments in Albania (although not much) and this became one more reason why Italy could not touch Albania ${ }^{3}$. However the English and French diplomacy could not make it, especially because it did not want to referee between countries. this became apparent after 1930s when two major British oil companies (Standard Oil and Anglo Persian Petroleum) retreated its investments from Albania after claiming to see no results. By taking into consideration that Italy had a massive interest in the destabilization of Albania, UK was pushing that our King Zog tie our relations with Rome. A. Chamberlain (foreign minister) informed Mussolini that he felt pressured by King Zog and felt that the King should in future address any

1 Puto, Arben. "Ballkani dhe fuqitë e Mëdha", Studime Historike, 1990, nr.1, pg.186

2 Puto, Arben. Shqipëria politike 1912-1939, Tiranë. 2009 , pg. 298

3 Teli(Dibra), Pranvera. Shqipëria dhe Diplomacia angleze 1919-1927. Tiranë 2005, pg.366 
complaints to Rome itself. ${ }^{4}$ Therefore it becomes apparent that after April 1939 where the Italian army acted out, UK did not hold a strong enough ground against Italy's motives although it was promising to unite conflicting countries.

\section{The New Albania, Italian Invasion}

Ciano's and Mussolini's declarations stated that Albania's independence would not be harmed however those declarations proved to be false. A week after the invasion, 14th April, Vittore Emmanuelle III became the King of Italy and Albania. Albania allowed that they have their own Italian army in power but this did not last long. Everything was decided by their King and Albanian border officers were replaced by Italians. Until June 1939, most of the threats that were made against the Albanian Kingdom were realised and Albania was now fully invaded. After the West's brief involvement in this case, they now had a new problem. This was that they failed to recognise Albania as a new found state. Great Britain began to analyze the state of things and they stated that a solution must be placed that benefits everyone. "We retreat from any involvement in the progression of countries. The disadvantage of reaching a decision concerning the invasion of Albania is that we would be accused of interfering and lose influence"5. However according to FO, the more time that passed, the easier it became to reach a decision. As FO states, The Italian army involvement in Albania was for the greater good. Italy justifies its actions by saying that Albanians wished for this involvement but this argument failed to convince. It is now clear that the situation that Albania is in, was created by installing fear and threatening the use of force in order to break the resistance of Albania population. ${ }^{6}$

For Great Britain, The Albanian invasion was a state of reality that they did not want to get involved with. Albania was seen purely as an Italian interest and not just a product of Mussolini's fascism. FO made it clear that nothing but a war could retreat the Italian army from Albania. ${ }^{7}$ This will not even happen if there was to be a total collapse of fascism in Italy. Therefore Albania's stance was whether they would declare their new independence sooner rather than later. ${ }^{8}$ As far as GB was concerned, their diplomacy and their two facedness between de jure and de facto began in fact to cause them more problems than anticipated. According to A. Nolan of FO "the stance that Great Britain should have maintained is that of a moral and ethical one".

He also goes on to say that "there are a lot of things that could be said in Italy's defence in its actions as they had long waited for the chance to invade Albania but the methods they followed in the matter were ugly. Especially given the fact that they chose to do this on a special day known by the Albanians "good Friday", this was the very day that the queen had given birth to a boy; therefore this caused a state of terror all over Albania. In order to accept the invasion, you have to not only accept that, but also deal with the way into which it was done. This was not the only argument against the invasion, our involvement would have had a big impact in a lot of surrounding countries, especially in America. ${ }^{9}$

For political reasons, Britain was invited to acknowledge the current state of things so that they avoid any misunderstanding with Italy. At this point Mussolini's government played a massive part in the reaction from Britain. Britain, in the hope of avoiding any conflict with Italy, became civil and developed good relationships with them. Therefore it is for this reason that the new state of Albania could not easily be accepted as it would cause conflict. From a political standpoint, the damage that was done to Albania by Italy will reveal itself. Previous history has shown us that when a country's independence is not recognised, it causes problems. In this case, the relationship between the two countries is damaged verging on irreparable. In the long run, this causes problems between diplomatic officials. At this point in time, it is important that matters do not become more complicated than they are already especially given the fact that Mussolini is in power.

The only facts that we can publically use in aiding matters between Albania and Italy is the example of Ethiopia which showed us that there is nothing to gain from refusing to accept facts as they are. It should however be made clear that our acknowledgment of Albania joining forces with Italy does not mean that we accept the methods that were used in obtaining this condition of matters. This has also been reinforced by the Prime Minister on 13 April. "If we decide to acknowledge Italy in our country, we have to inform them that we will not agree until Italian army troops move out of Spain. We also have to inform the Italian Press that the fact that we acknowledge the current situation, does not mean

\footnotetext{
${ }_{4}^{4}$ Puto, Arben. Shqipëria politike 1912-1939, Tiranë. 2009, pg. 408

5 PRO FO 37121716 R 3593/ 2066/90 Foreing Office minutes, Sir. A.Noble, 24 April 1939

${ }_{6}^{6}$ PRO FO 37121716 R 3593/ 2066/90 Foreing Office minutes, Sir. A.Noble, 24 April 1939

7 PRO FO 37121716 R 3593/ 2066/90 Foreing Office minutes, Sir. A.Noble, 24 April 1939

8 PRO FO 37121716 R 3593/ 2066/90 Foreing Office minutes, Sir. A.Noble, 24 April 1939

9 PRO FO 37121716 R 3593/ 2066/90 Foreing Office minutes, Sir. A.Noble, 24 April 1939 
that we approve of the methods that were used"..$^{10}$ Therefore the acknowledgment of the new state of Albania began by the issuing of the new passports provided by the Italians in the year 1939. this also meant that the Albanians accepted Vittore Emmanuelle III as the king of Albania and Italy. Demonstrations were held that showed that the British Prime Minister N Chamberlain was ready to accept the De Jure acknowledgment besides the criticism by the public. the reason for this is because he believed that Albania would find it impossible to remain de facto for long. ${ }^{11}$ On the other hand, the USA would give Albania its full backing and recognise the new state as independent. On an ambassador meeting in Washington, R Lindsay and Grisby stated that they did not understand where the problem stood with Britain recognising Albania and its new regime. Albania does not have a strong influence in USA, even after their acknowledgment of the regime, they would soon forget about it. ${ }^{12}$ However on the 2 June 1939, FO demanded to know the stance that Washington would maintain towards Albania and the Italian army involvement, and their reply was that they did not know as yet. "USA is still not sure about the status of Albanian regime and we wish to do further analysis there. At the same time the communication between the US diplomats and the Albanian authorities in Tirana remains friendly and unofficial. ${ }^{13}$

At the end of June, Britain retreated its diplomacy from Durres and therefore gave Italy full backing. When this happened, it meant that the situation was now de facto and that Britain did no longer support the Albanians. However, this did not mean that the British left Albania for good. The British government removed the diplomatic repreentatives and instead places a permanent Consul. FO found that this solution would not cause any problems and as the Italians themselves had around 98 Consul Embassies in London and according to Colonel Office, these embassies served more espionage than Consul services. ${ }^{14}$ This was seen as the next step and it was good news for Britain as the workload was halved but they were still in the know when it came to important information. So this meant that it was really important that someone experinced was in this Consul Embassy position. ${ }^{15}$

Until September, the new status of Albania was not only dependent on building good relationship with the Italians, but also keeping good with the other countries. For Britain it was equally important that they maintained a good relationship with Yoguslavia as they did with USA and France. The Serbs were very threatened by the Italians movement and as The Pavle Prince openly said to R Campbell "The fact that the British acknowledge the status of Albania and agree with the Italians is not the best of movements". ${ }^{16}$ On the other hand, Yougoslavia also agreed that Italy should be the decision maker behind Albania therefore contradicting their previous statements. They even recognised that the King of Italy was also the King of Albania. As A. Noble declared "We can not be more catholic that the Pope and the FO is completely in the favour of the new Albanian status". ${ }^{17}$ For Britain this was seen as a chance to manipulate Italy as in order for their help towards achieving a new status for Albania, they would later demand favours. ${ }^{18} \mathrm{HMG}$ did not prefer to put a price on this new status acknowledgment. The relationship with the Italians was sensitive and he didnt find it suitable to put a price on this status. For FO, the new status was to be seen as routine, something that happened without causing too much of a stir. The only request that was to be put on the Italians was that they dont go to the press with these issues. ${ }^{19}$ On the 14 November 1939, Lord Halifax asked the British diplomats to accept the new Albanian status, however they were not to go into depth as to how far they accepted the situation. The acceptable answer was to be that "We accepted this situation for the greater good and to improve the services that our Consul have to offer"20. This was to improve the relations with Italy although it was not to be declared openly. It was to be called spontaneous and the right moral decision so that the public may be kept happy. According to FO; the reason for the invasion was so that they follow into Germany's footsteps into entering Western Europe. Therefore this was a major reason that it was very important for

10 PRO FO 37121716 R 3593/2066/90 Foreing Office minutes, Sir. A.Noble, 24 April 1939

11 PRO FO 37121716 R 3593/ 2066/90 Foreing Office to R . Lindsay(Washington), E.Phipps(Paris), 3 May 1939

12 PRO FO 37121716 R 3758/2066/90 Sir R. Lindsay( Washington) to Foreing Office 8 May 1939

13 PRO FO 37121716 R 4830/ 2066/90 Sir R. Lindsay( Washington) to Foreing Office Aide Memoire from State Departament; 2 June 1939

14 PRO FO 371. 23717 R 5008/2066/ 90 Question of replacament of british legation in Durazzo by consolate general 22 June 1939

15 PRO FO 371. 23717 R 5008/2066/90 Question of replacament of british legation in Durazzo by consolate general 22 June 1939 . FO minutes, A. Noble

${ }_{16}$ PRO FO 371. 23717 R 9376/2066/ 90 Foreing office minute (Sir A.Noble) 23 October 1939

17 PRO FO 371. $23717 R$ 9376/2066/ 90 Foreing office minute (Sir A.Noble) 23 October 1939

18 PRO FO 371. 23717 R 4230/2066/ 90 From E.Phipps(Paris), 12 August 1939

19 PRO FO 371. $23717 R$ 9376/2066/ 90 Foreing office minute (Sir A.Noble) 23 October 1939

20 PRO FO 371. 23717 R 9586/2066/ 90 Foreing Office, Circular, L. Halifax, 14 November 1939 
Mussolinni that Britain recognise the new status and give their full backing. ${ }^{21}$ But it was to be seen later that the politics concerned with keeping the peace followed by Chamberlain, were simply not enough to stop dictators like Mussolinni and Htiler into dominion.

A day after the the British Ambassador was called to Rome so that he may present the findings from the Consul Embassy that was in Durres, the Albanian immigrants located in Paris went into upheaval and protested in front of the British Embassy. The reason for this is that it was now fully understood that Britain was backing the Italians. King Zog sends a letter to King George I demanding that he does not allow his officials for this involvement. "It is a sure thing that the public can see the transparency of Britain's actions and it is nothing but backing of a fascist. The Albanian public now consider this as a loss of freedom and complete dissapointment in the Western countries which promise to be fair and ethical". This letter was accompanied by a document that asked to be handled as they would sovereignety ( to be more precise it was a letter between a sovereign and ish-sovereign). ${ }^{22}$ However it was clear that for Britain, the case concerning Albania was over and dealt with. 